\title{
Inhibition of IL-8 Production by Green Tea Polyphenols in Human Nasal Fibroblasts and A549 Epithelial Cells
}

\author{
In-Bae KIm, Dong-Young Kim, Su-Jin LeE, Min-Jung Sun, Myung-Sook LeE, Hua LI, \\ Jeong-Je CHO, and Cheung-Seog PARK* \\ Department of Microbiology, College of Medicine, Kyung Hee University; \#1 Hoegi-dong, Dongdaemun-gu, Seoul \\ 130-701, Korea. $\quad$ Received October 17, 2005; accepted March 1, 2006
}

\begin{abstract}
The attraction of leukocytes to tissues is essential in order for inflammation and the host response to infection to occur. Airway inflammation is a very common cause illness with a substantial impact on health care. Neutrophils play an essential role in the host defense and in inflammation, but the latter may trigger and sustain the pathogenesis of a range of acute and chronic diseases. Infiltration of neutrophils occurs as a response to chemoattractant molecules by resident tissue cells. The recruitment of neutrophils in airway inflammation may account for the generation of IL-8. To evaluate the effectiveness of green tea polyphenols in the modulation of airway inflammation through the blocking of neutrophil chemokine production, nasal mucosal fibroblasts and A549 bronchial epithelial cells were analyzed for the production of IL-8. Both nasal mucosal fibroblasts and bronchial epithelial cells produced significant amounts of IL-8 through stimulation of IL-1 $\beta$. Tea polyphenols were very effective in the inhibition of IL-8 production. Among the polyphenols tested, EGCG and ECG showed strong inhibitory activity in dose-dependent manners. EGC and EC showed moderate inhibition at $48 \mathrm{~h}$ culture, whereas (-)catechin was not effective. Production of IL-8 after stimulation by proinflammatory cytokines in both nasal fibroblasts and bronchial epithelial cells was significantly blocked by pretreatment with green tea polyphenols.
\end{abstract}

Key words green tea polyphenol; IL-8; inflammation

The attraction of leukocytes to tissues is essential in order for inflammation and the host response to infection to occur. The process is controlled by chemokines, a term which refer to chemotactic cytokines. ${ }^{1,2)}$ In their monomeric forms, chemokines are 8 - to $10-\mathrm{kD}$ proteins with 20 to $70 \%$ homology in amino acid sequences, and are characteristically basic heparin-binding proteins, which facilitate binding to cells and matrix components. There are at least four chemokine families, but only two have been extensively characterized. These two subfamilies, which contain four cyteines, appear to be the largest groups. They can be distinguished according to the position of first two cysteines, which either are separated by one amino acid (CXC chemokine) or are adjacent to each other (CC chemokines). The CXC chemokines can be further subdivided into those that contain the sequence glutamic acid-leucine-arginine (ERL) near the N-terminal, and those that do not. ${ }^{3)}$ The $\mathrm{CXC}$ chemokines that contain the sequence are chemotactic for neutrophils, whereas those that do not contain in the sequence act on lymphocytes.

Airway inflammation is a very common cause of illness with a substantial impact on health care. Neutrophils play an essential role in the host defense and in inflammation, but the latter may trigger and sustain the pathogenesis of a range of acute and chronic diseases. Infiltration of neutrophils occurs as a response to chemoattractant molecules by resident tissue cells. The recruitment of neutrophils in airway inflammation may account for the generation of interleukin 8 (IL-8), the prototypic CXC chemokine. IL-8 was identified as an agonist for neutrophils on the basis of two in vitro effects chemotaxis and the release of granule enzymes. As a result, the biological activities of IL-8 on neutrophils and the mechanism of signal transduction have been studied in great detail, and their effects have been compared with those of well-characterized neutrophil attractants such as C5a, fMet-Leu-Phe, platelet activating factor (PAF), and leukotriene (LT) B4. ${ }^{4,5}$ )

The observation that IL- 8 is a product of monocytes and macrophages and is also generated by tissue cells, was very important to understanding of the numerous potential implications of this chemokine in inflammatory conditions. IL- 8 is associated with rhinitis, ${ }^{6)}$ bronchitis, ${ }^{7)}$ pulmonary fibrosis, ${ }^{8)}$ psoriasis, ${ }^{9}$ inflammatory bowel disease, ${ }^{10)}$ and other disorders. Several other chemokines, such as growth-related oncogene (GRO)- $\alpha$ and ENA-78, are also potent neutrophil chemoattractants; this property depends on the presence of ERL motifs. ${ }^{2)}$

The promoter of the IL- 8 gene contains a binding site for the redox-responsive transcription factors, NF- $\kappa \mathrm{B}$, which have been shown to be important for IL-8 expression. ${ }^{11,12)}$ Activation of nuclear factor- $\kappa \mathrm{B}(\mathrm{NF}-\kappa \mathrm{B})$ acts as a master switch or control point for the expression of a large number of proinflammatory genes. ${ }^{13)} \mathrm{NF}-\kappa \mathrm{B}$, a member of the Rel family of transcription factors, is usually present in the cytoplasm of the cell in an inactive state bound to a related inhibitory protein known as $\mathrm{I} \kappa \mathrm{B}$. I $\kappa \mathrm{B}$ physically masks the nuclear translocation of NF- $\kappa \mathrm{B}$, thereby retaining it in the cytoplasm in an inactive state. A common pathway for the activation of NF- $\kappa \mathrm{B}$ occurs when $\mathrm{I} \kappa \mathrm{B}$ is phosphorylated by the $\mathrm{I} \kappa \mathrm{B}$ kinase. Phosphorylated $\mathrm{I} \kappa \mathrm{B}$ is targeted for rapid ubiquitination, which results in degradation by the $26 \mathrm{~S}$ proteasome. Degradation of $\mathrm{I} \kappa \mathrm{B}$ unmasks the nuclear translocation sequence of NF- $\kappa \mathrm{B}$, allowing NF- $\kappa \mathrm{B}$ to enter the nucleus and direct transcription of target genes. ${ }^{14)}$

Polyphenols are widespread in nature; the two most important groups of dietary phenolics are the phenolic acids and the flavonoids, the latter being the largest and most extensively studied group. One abundant source of dietary phenolics is green tea, the compounds of which are mainly flavonols or catechins. ${ }^{15)}$ In brewed green tea, the water-extractable material, which usually accounts for one-third of the tea leaves in dry weight, contains approximately $30 \%$ catechins, 3\% flavonols, $3-6 \%$ caffeine, and a variety of other constituents. 
The green tea polyphenols include epigallocatechin gallate (EGCG), epigallocatechin (EGC), epicatechin gallate (ECG), epicatechin (EC), gallocatechin (GC), and (-)catechin. Among these polyphenols, EGCG is the major polyphenol component of the green tea. To gain insight into the mechanisms that are responsible for the anti-inflammatory effect of green tea, several green tea polyphenols were analyzed for their ability to block the induction of IL-8; these analyses used primary human nasal mucosal fibroblasts and A549 bronchial epithelial cells.

\section{MATERIALS AND METHODS}

Reagents EGCG, EGC, ECG. EC, and (-)catechin were purchased from Sigma. Recombinant human IL-1 $\beta$, IL-4, IL13 , tumor necrosis factor (TNF)- $\alpha$, interferon (IFN)- $\gamma$ were purchased from R\&D Systems (Minneapolis, MN, U.S.A.). Dulbecco's modified Eagle's medium (DMEM) and fetal bovine serum (FBS) were purchased from GIBCO-BRL.

Cell Culture To isolate and propagate human nasal mucosal fibroblasts (HNMFs), inferior turbinate mucosa samples were collected from patients with septal deviation at the time of surgery for correction. Surgically removed mucosa specimens were cut into several pieces and then incubated for $30 \mathrm{~min}$ at $37^{\circ} \mathrm{C}$ in DMEM containing $0.25 \%$ collagenase. Following incubation in collagenase, these tissue sections were transferred to $10 \mathrm{ml}$ of phosphate buffered saline (PBS) containing penicillin-streptomycin. Epithelial cells and microvascular endothelial cells were released into PBS by applying pressure on the tissue across the surface with a pair of curved forceps several times. HNMFs were isolated from the specimens by explant cultures following the removal of epithelial cells and endothelial cells. The attached explants were cultured with DMEM containing 2\% FBS and antibiotics. After a period of 3 to 4 weeks, when the growth of fibroblasts was established, tissue sections were removed and the first passage was performed. Cultures were maintained for up to five or six passages.

HNMFs from the fifth or sixth passage were cultured directly onto collagen-type-I coated, 24 well culture plate (Corning-costar). A 549 cells, derived from a lung non-small cell adenocarcinoma with the alveolar type II phenotype, purchased from ATCC were used in this experiment. Cells were plated on $100-\mathrm{mm}$ plates and cultured in DMEM supplemented with 10\% heat-inactivated FBS (Hyclone) and penicillin-streptomycin (GIBCO BRL). Cultures were grown in $5 \% \mathrm{CO}_{2}$ at $37^{\circ} \mathrm{C}$ and passaged every $4 \mathrm{~d}$.

Cytokine and Polyphenol Treatment Cultivated confluent fibroblasts and A549 cells were incubated with various tea polyphenols in concentrations of 2,10 , and $50 \mu \mathrm{g} / \mathrm{ml}$ of culture medium for $24 \mathrm{~h}$. And then, cultures were stimulated with recombinant human IL-4, IL-13, tumor necrosis factor (TNF)- $\alpha$, interferon (IFN)- $\gamma$ in a concentration of $10 \mathrm{ng} / \mathrm{ml}$ for another $24 \mathrm{~h}$. IL-1 $\beta$ was used in a concentration of $1 \mathrm{ng} / \mathrm{ml}$ for another $24 \mathrm{~h}$. Supernatants were collected and stored frozen at $-80^{\circ} \mathrm{C}$ until use.

ELISA for IL-8 Flat-bottomed 96-well microtiter plates (Corning) were coated with $1 \mu \mathrm{g} / \mathrm{ml}$ of mouse anti-human monoclonal IL-8 antibody (100 $\mu \mathrm{l} /$ well) in PBS, and incubated overnight at $4{ }^{\circ} \mathrm{C}$ and blocked with $100 \mu \mathrm{l} /$ well of blocking solution (1\% BSA, 0.05\% Tween 20 in PBS) for $1 \mathrm{~h}$ at room temperature; $100 \mu \mathrm{l}$ of the standard or sample was added to each well and incubated for $2 \mathrm{~h}$ at room temperature. Next, $100 \mu \mathrm{l}$ of the biotinylated goat anti-human IL-8 antibody (R\&D) in assay buffer $(0.1 \%$ BSA, $0.05 \%$ in PBS) was added and incubated for $1 \mathrm{~h}$ at room temperature. Thereafter, $100 \mu \mathrm{l}$ of the avidin-horseradish peroxidase conjugate (Vector Laboratories, Burlington, CA, U.S.A.) (diluted 2000fold in assay buffer) was added to each well and incubated for $30 \mathrm{~min}$ at room temperature. Finally, $100 \mu \mathrm{l}$ of substrate solution per well was added and the mixture was incubated for $10 \mathrm{~min}$ at room temperature. The enzyme reaction was stopped with $100 \mu \mathrm{l}$ of $2 \mathrm{~mol} / \mathrm{H} \mathrm{H}_{2} \mathrm{SO}_{4}$ and the absorbance at $450 \mathrm{~nm}$ was measured in a microtiter plate reader. The sensitivity of this assay was $5 \mathrm{pg} / \mathrm{ml}$.

Western Blot Analysis Treated cells were washed once in PBS and lysed in ice-cold lysis buffer containing $50 \mathrm{~mm}$ (pH 8.0), $110 \mathrm{~mm} \mathrm{NaCl,} 5$ mm EDTA, 1\% Triton X-100, and PMSF $(100 \mu \mathrm{g} / \mathrm{ml})$. Protein concentrations were determined using the Bradford assay (BioRad, Hercules, CA, U.S.A.). Whole cell lysates containing $25 \mu \mathrm{g}$ of protein were boiled in equal volumes of loading buffer (125 mm Tris- $\mathrm{HCl}, \mathrm{pH} 6.8$, $4 \%$ SDS, $20 \%$ glycerol, and 10\% 2- $\beta$-mercaptoethanol). Proteins were separated electrophoretically on $15 \%$ Tris-glycine gels and subsequently transferred to PVDF membranes using the Novex Xcell Mini-Gel system. For immunoblotting, membranes were blocked with 5\% non-fat dried milk in Trisbuffered saline (TBS) for $1 \mathrm{~h}$. Primary antibody against the $\mathrm{I} \kappa \mathrm{B} \alpha$ or $\beta$-actin (Santa Cruz Biotechnology, Santa Cruz, CA, U.S.A.) were applied at $1: 1000$ dilutions for $1 \mathrm{~h}$. After washing twice with TBS containing $0.05 \%$ Tween 20 (TTBS), secondary antibody (peroxidase-conjugated goat antirabbit immunoglobulin G, Stressen, Victoria, British Columbia) was applied at 1:5000 dilution for $1 \mathrm{~h}$. Blots were washed in T-TBS twice for $10 \mathrm{~min}$, visualized by enhanced chemiluminescence (ECL, Labfrontier, Korea).

Quantitative Reverse Transcriptase-Polymerase Chain Reaction (RT-PCR) Total RNA was prepared from IL- $1 \beta$ stimulated A549 cells by Trizol method. Total RNA $(1 \mu \mathrm{g})$ was reverse transcribed into cDNA in a total volume of $20 \mu \mathrm{l}$ using random primers and revertAid M-MuLV reverse transcriptase (Fermentas, vilnius, Lithuania). PCR amplification was conducted in a total volume of $50 \mu \mathrm{l}$ of $1 \times \mathrm{PCR}$ buffer (Takara, Shuzo, Otsu, Japan) containing $1.0 \mu \mathrm{l}$ of the firststrand cDNA, $25 \mathrm{~mm}$ of dNTP, $2 \mu \mathrm{M}$ of each primer and $2.5 \mathrm{U}$ of Taq DNA polymerase.

The following oligonucleotides were used: hIL-8 sense primer 5'-ACATGACTTCCAAGCTGGCCGTGG-3'; hIL-8 antisense primer $5^{\prime}$-GTATGTTCTGGATATTTCATGGTAC3'; GAPDH sense primer 5'-ATCACCATCTTCCAGGAGCG-3'; GAPDH antisense primer 5'-GATGGCATGGACTGTGGTCA-3'.

Cycle parameters were: annealing $0.5 \mathrm{~min}$ at $58^{\circ} \mathrm{C}$, elongation $1 \mathrm{~min}$ at $72{ }^{\circ} \mathrm{C}$ and denaturation $1 \mathrm{~min}$ at $94^{\circ} \mathrm{C}$. Resulting PCR products were separated in 1\% agarose gel and analyzed by gel documentation system. Sequences of the hIL-8 and GAPDH were amplified out of each cDNA batch with 28 and 22 amplification cycles, respectively. 


\section{RESULTS}

Effects of Cytokines on the Production of IL-8 in Human Nasal Mucosal Fibroblasts and A549 Epithelial Cells Without cytokine stimulation, nasal fibroblasts produced negligible amounts of IL-8. IL-4, the representative Th2 cytokine, and proinflammatory cytokines such as TNF- $\alpha$ and IL- $1 \beta$ were found to be good inducers of IL- 8 production in nasal mucosal fibroblasts. When used in combination with IL-4 or IL-13, TNF- $\alpha$ treatment showed synergistic induction of the IL-8 induction. Treatment with only IL-13 did not induce IL-8 production. When IL-13 was used in combination with TNF- $\alpha$, it was less potent than IL-4 in inducing IL-8 production. Among the cytokines used in this experiment, treatment with only IL- $1 \beta$ was superior in inducing IL8 production. IFN- $\gamma$ did not induce IL- 8 production and showed slight inhibitory activity when used in combination with proinflammatory cytokines (Fig. 1).

In contrast to fibroblasts, A549 cells produced IL-8 without any cytokine stimulation. A549 cells were responsive only to proinflammatory cytokines, such as TNF- $\alpha$ and IL$1 \beta$ in inducing IL- 8 production. The induction of IL- 8 production by proinflammatory cytokines was inhibited by Th2 cytokines such as IL-4 and IL-13. As was in fibroblasts, IL$1 \beta$ was most potent stimulus for IL- 8 induction in A549 cells. IFN- $\gamma$ was inhibitory to the induction of IL- 8 when used in combination with TNF- $\alpha$ (Fig. 2).

Inhibitory Effects of Green Tea Polyphenols on IL-1 $\beta$ Induced IL-8 Production of Nasal Fibroblasts and A549 Epithelial Cells Among the tea polyphenols used for pretreatment in nasal fibroblasts, EGCG and ECG were very effective in inhibiting IL- $1 \beta$-induced IL- 8 production and both showed dose-dependent inhibitory patterns. EGC and EC showed inhibitory effects at high concentrations, but $(-)$ catechin did not show any significant inhibitory activity (Fig. 3 ).

Inhibitory patterns of tea polyphenols in A549 cells were similar, but slightly different from those of fibroblasts (Fig. 4). EGCG showed very strong inhibitory activity in a dosedependent manner; at a concentration of $50 \mu \mathrm{g} / \mathrm{ml}$, it almost completely inhibited IL-8 induction. EGC significantly inhib-

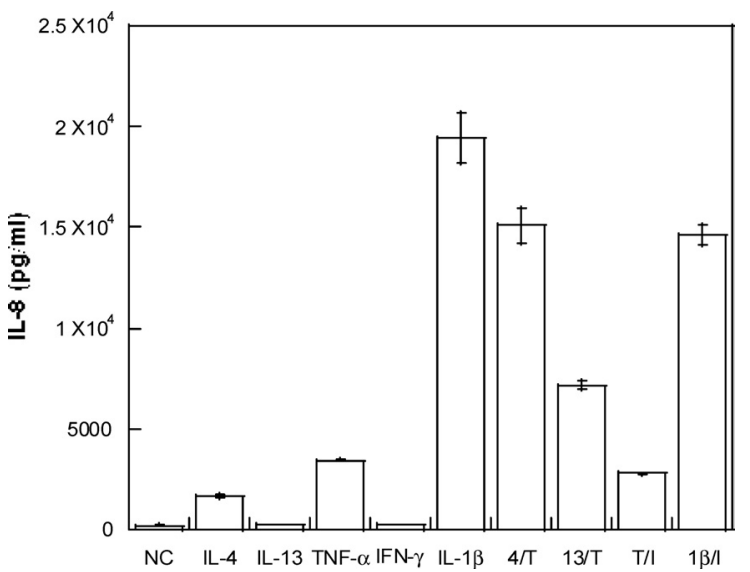

Fig. 1. Effects of Cytokines on IL-8 Production in Human Nasal Mucosal Fibroblasts (HNMFs)

Confluent monolayers of HNMFs were stimulated with IL-4 $(10 \mathrm{ng} / \mathrm{ml})$, IL-13 $(10 \mathrm{ng} / \mathrm{ml})$, TNF- $\alpha(10 \mathrm{ng} / \mathrm{ml}), \mathrm{IL}-1 \beta(1 \mathrm{ng} / \mathrm{ml}), \mathrm{IFN}-\gamma(10 \mathrm{ng} / \mathrm{ml}), 4 / \mathrm{T}$; IL-4 and TNF$\alpha, 13 / \mathrm{T}$; IL-13 and TNF- $\alpha$, T/I; TNF- $\alpha$ and IFN- $\gamma, 1 \beta / \mathrm{I}$; IL- $1 \beta$ and IFN- $\gamma$ and NC; non-stimulation. These cytokines were used alone or in combination for $24 \mathrm{~h}$. IL-8 levels in the supernatants were quantitated by ELISA. ited IL- 8 only at high concentrations. Unlike of fibroblasts, the inhibitory activities of EC in A549 cells were not significant.

Inhibitory Effects of Tea Polyphenols on IL-8 Production of Nasal Fibroblasts during Incubation The tea polyphenols and IL- $1 \beta$ were simultaneously added to fibroblast cultures in order to evaluate the responsiveness of cells to inhibitors in the production of IL- 8 according to incubation time. IL- $1 \beta$-induced IL- 8 production was initiated from $8 \mathrm{~h}$ and accumulated throughout the incubation time, for up to $48 \mathrm{~h}$. EGCG inhibited IL-8 production of fibroblasts upon the stimuli of IL- $1 \beta$.

When the level of IL- 8 was measured at the $48 \mathrm{~h}$ time point, all of tea polyphenols effectively inhibited IL-8 production (Fig. 5).

Inhibitory Effects of Tea Polyphenols on IL-8 mRNA Expression of A549 Epithelial Cells As tea polyphenols

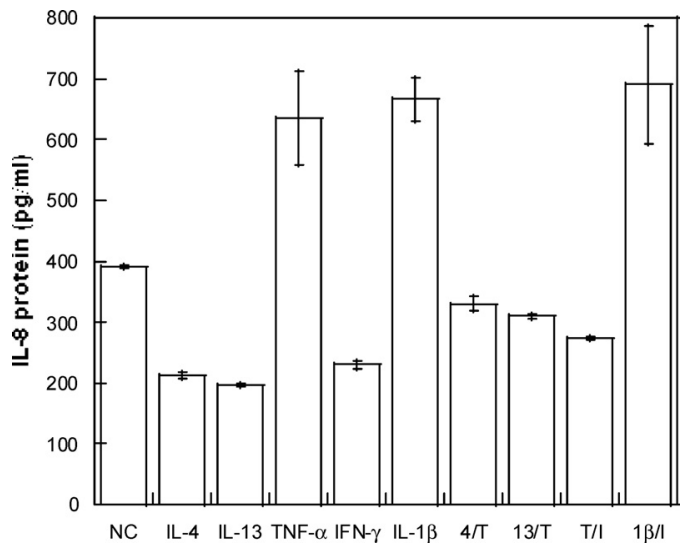

Fig. 2. Effects of Cytokines on IL-8 Production in A549 Bronchial Epithelial Cells

Confluent monolayers of A549 cells were stimulated with IL-4 $(10 \mathrm{ng} / \mathrm{ml})$, IL-13 $(10 \mathrm{ng} / \mathrm{ml})$, TNF- $\alpha(10 \mathrm{ng} / \mathrm{ml}), \mathrm{IL}-1 \beta(1 \mathrm{ng} / \mathrm{ml}), \mathrm{IFN}-\gamma(10 \mathrm{ng} / \mathrm{ml}), 4 / \mathrm{T}$; IL-4 and TNF$\alpha, 13 / \mathrm{T}$; IL-13 and TNF- $\alpha$, T/I; TNF- $\alpha$ and IFN- $\gamma, 1 \beta / \mathrm{I}$; IL- $1 \beta$ and IFN- $\gamma$ and NC; non-stimulation. These cytokines were used alone or in combination for $24 \mathrm{~h}$. IL- 8 levels in the cell supernatants were quantitated by ELISA.

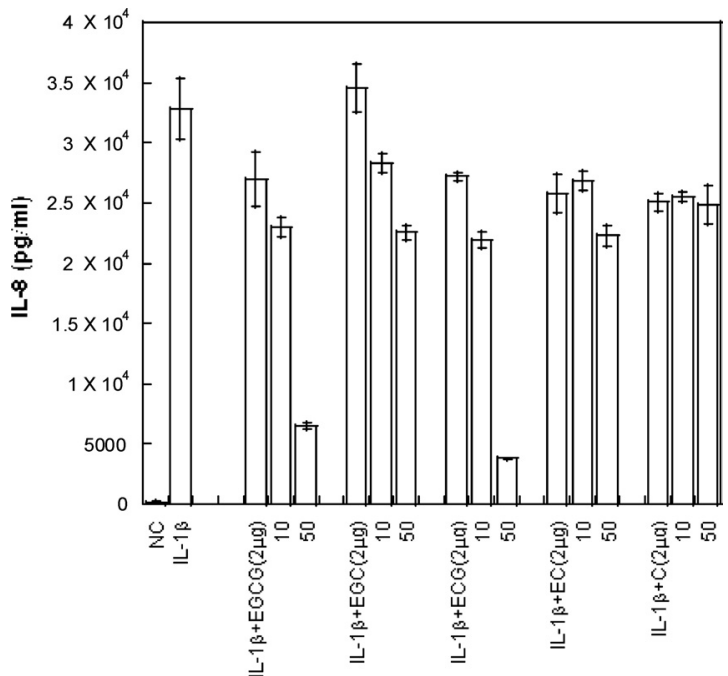

Fig. 3. Inhibition of IL-1 $\beta$-Induced IL-8 Production in Nasal Mucosal Fibroblasts by Green Tea Polyphenols

Confluent monolayers of nasal mucosal fibroblasts were pretreated with 2,10 , or $50 \mu \mathrm{g} / \mathrm{ml}$ of EGCG, EGC, ECG, EC, and (-)catechin and non-stimulation (NC), respectively, for $24 \mathrm{~h}$, and were then stimulated with $1 \mathrm{ng} / \mathrm{ml}$ of $\mathrm{IL}-1 \beta$ for another $24 \mathrm{~h}$. IL-8 levels in the cell supernatants were quantitated by ELISA. 


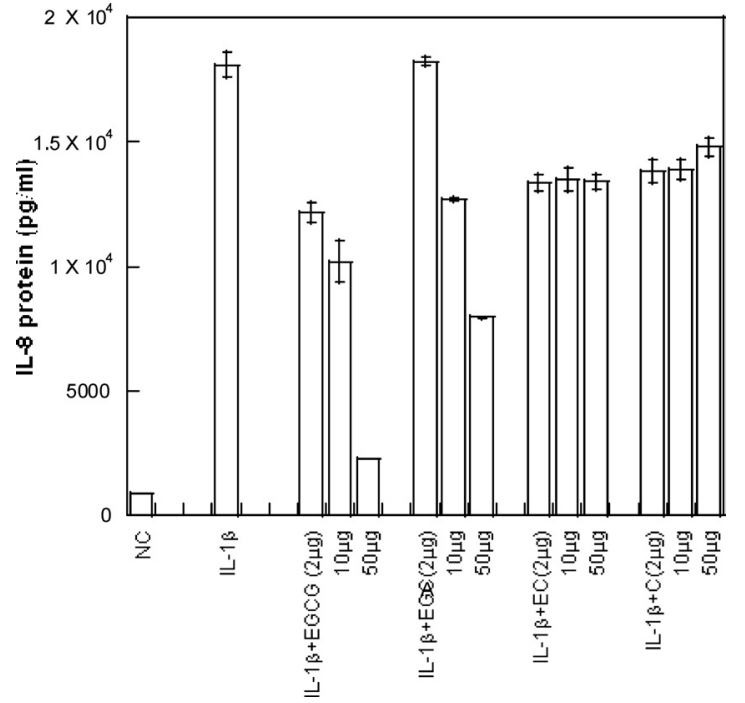

Fig. 4. Inhibition of IL- $1 \beta$-Induced IL-8 Production by Green Tea Polyphenols in A549 Bronchial Epithelial Cells

Confluent monolayers of A549 bronchial epithelial cells were pretreated with 2, 10, and $50 \mu \mathrm{g} / \mathrm{ml}$ of EGCG, EGC, ECG, EC, and (-)catechin, respectively, for $24 \mathrm{~h}$, and were then stimulated with $1 \mathrm{ng} / \mathrm{ml}$ of IL- $1 \beta$ for another $24 \mathrm{~h}$. IL-8 levels in the cell supernatants were quantitated by ELISA.

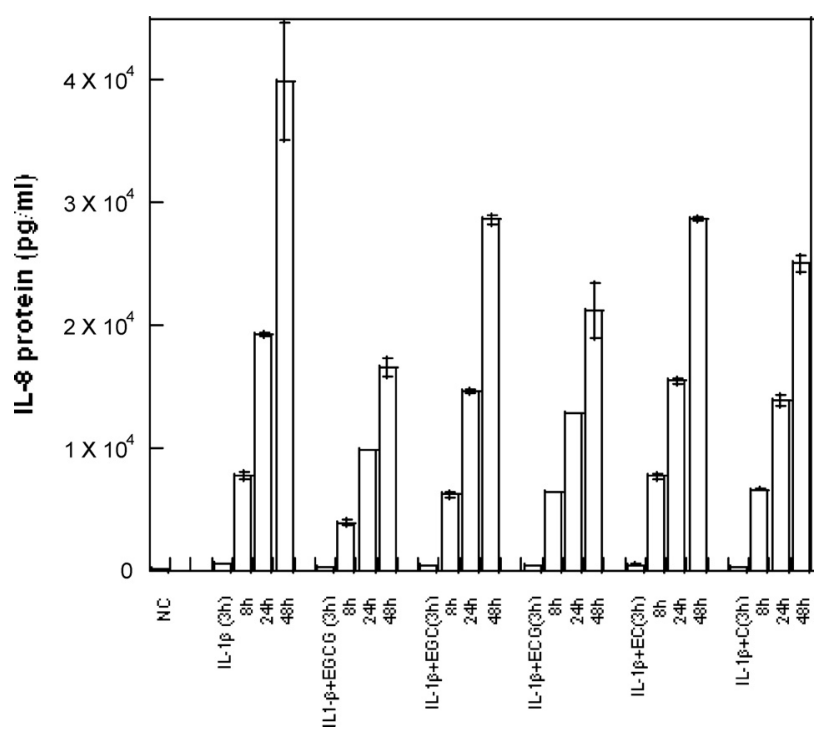

Fig. 5. Inhibitory Patterns of Tea Polyphenols on IL-8 Production in Nasal Mucosal Fibroblasts during Incubation

$10 \mu \mathrm{g} / \mathrm{ml}$ of the tea polyphenols were added to fibroblast cultures in combination with IL- $1 \beta$, and the cultures were incubated for up to $48 \mathrm{~h}$. Culture supernatant was obtained at $3,8,24$, and $48 \mathrm{~h}$ time points. IL- 8 levels in the cell supernatants were quantitated by ELISA.
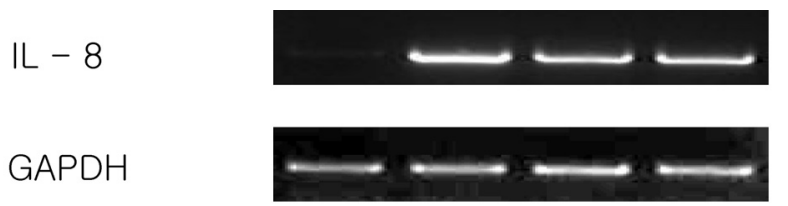

Integrated density (IOD)
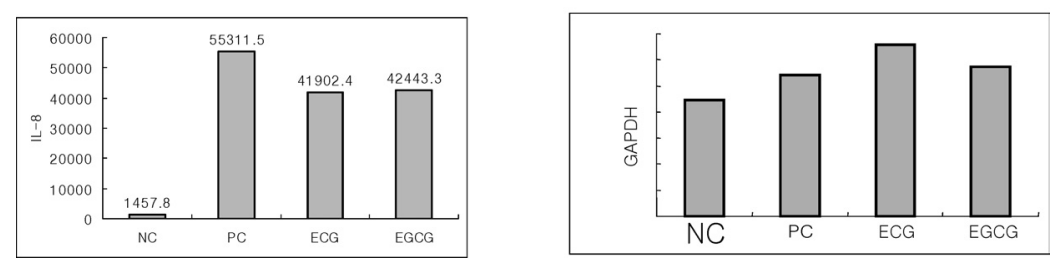

Fig. 6. Inhibition of IL-8 mRNA by Green Tea Polyphenols in A549 Bronchial Epithelial Cells

Confluent monolayers of A549 bronchail epithlial cells were pretreated with $50 \mu \mathrm{g} / \mathrm{ml}$ of EGCG or ECG for $24 \mathrm{~h}$, and were then stimulated with $1 \mathrm{ng} / \mathrm{ml}$ of IL-1 $\beta$ for $3 \mathrm{~h}$. Expression of IL-8 mRNA was determined by reverse transcriptase polymerase chain reaction.

effectively inhibited IL-8 production (Fig. 5), we next determined the effects of ECG, EGCG on IL-1 $\beta$-mediated expression of IL-8 mRNA using RT-PCR. As shown in Fig. 6, treatment with IL-1 $\beta$ alone significantly increased IL-8 mRNA expression compared to control cells treated with media alone. Pretreatment with ECG and EGCG inhibited IL- $1 \beta$ mediated expression of IL-8 mRNA compared to IL- $1 \beta$ alone treated cells (Fig. 6).

Inhibitory Effects of Tea Polyphenols on IL-1 $\beta$ Mediated Degradation of $I K B$ in A549 Epithelial Cells As IL8 gene expression regulated, in part, by $\mathrm{NF}-\kappa \mathrm{B}$, we determined the effect of tea polyphenols on IL- $1 \beta$-mediated activation of $\mathrm{NF}-\kappa \mathrm{B}$ using I $\kappa \mathrm{B}$ degradation. Treatment with IL$1 \beta$ resulted in significant degradation of $\mathrm{I} \kappa \mathrm{B}$ compared to control cells treated with media alone (Fig. 7, lane 1 and 2). ECGC and ECG inhibited partially IL $-1 \beta$ mediated $\mathrm{I} \kappa \mathrm{B}$ degradation (Fig. 7, lane 3 and 4).

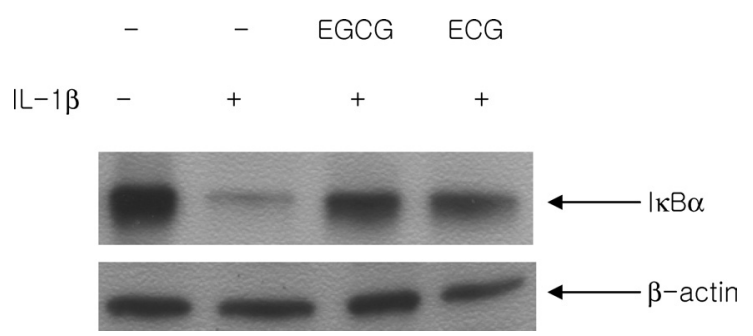

Fig. 7. Inhibition of Nuclear Factor $\kappa \mathrm{B} \alpha(\mathrm{I} \kappa \mathrm{B} \alpha)$ Degradation in A549 Cells by Green Tea Polyphenols

Confluent monolayers of A549 bronchial epithelial cells were pretreated with $50 \mu \mathrm{g} / \mathrm{ml}$ of EGCG or ECG for $2 \mathrm{~h}$, and were then stimulated with $5 \mathrm{ng} / \mathrm{ml}$ of IL- $1 \beta$ for $30 \mathrm{~min}$. The levels of cytosolic I $\kappa \mathrm{B} \alpha$ were determined by western blotting. Each lane was loaded with $25 \mu \mathrm{g}$ of cytosolic protein, and protein bands reacted with a I $\kappa \mathrm{B} \alpha$ or $\beta$-actin specific antibody were visualized by enhanced chemiluminnescence. 


\section{DISCUSSION}

In this study, we demonstrate that the tea polyphenols present in green tea are very effective in inhibiting the production of IL-8, one of the most powerful chemoattractants for neutrophils in the target tissues. IL-8 is able to induce profuse neutrophil recruitment without causing complete activation of these phagocytes, leading to the generation of reactive oxygen species (ROS). ${ }^{16)}$ Neutrophils play a pivotal role in the host defense and in inflammation. In the tissue, they act as phagocytic cells, and also release a variety of ROS and proteases. These mechanisms give neutrophils a key role in host defense. In addition, the neutrophil-mediated inflammatory responses may trigger and sustain the pathogenesis of a range of chronic diseases. The promoter of the IL-8 gene contains a binding site for the redox-responsive transcription factors, $\mathrm{AP}-1$ and $\mathrm{NF}-\kappa \mathrm{B}$, which have been shown to be important for IL-8 expression. ${ }^{11,12)}$

The consumption of foods or beverages containing polyphenols has been suggested to protect against chronic lung diseases such as chronic obstructive pulmonary disease, heart disease, chronic inflammation, and certain types of cancer. Tea drinking is an important source of fluid intake worldwide and ranks second only to water. As green tea generally is made with boiling water, it is a safe beverage, and is also much favored for its fragrance. In this beverage, EGCG is the most prevalent secondary metabolite, followed by EGC and ECG. After moderate green tea consumption, it is reported that the plasma concentration of EGCG reaches $0.1-0.3 \mu \mathrm{M}$; these easily achievable plasma concentrations angiogenesis, tumor cell invasion, and the activity of human leukocyte elastase. EGCG is also known as a direct inhibitor of matrix metalloproteinase (MMP)-2 and MMP-9, the two gelatinases most frequently overexpressed in cancer and angiogenesis, which are likely to be relevant mediators of extracellulr matrix degradation and airway remodeling. ${ }^{17)}$ EGCG, in particular, has been demonstrated to be an antioxidant and can block the activation of $\mathrm{NF}-\kappa \mathrm{B}$ by blocking the signal-induced phosphorylation of $\mathrm{I} \kappa \mathrm{B}{ }^{18)}$ Our result also showed ECG or EGCG block IL- $1 \beta$ mediated activation of NF- $\kappa$ B (Fig. 7). TNF- $\alpha$ is a rapid activator of IL- 8 gene expression and requires the presence of an inducible NF- $\kappa \mathrm{B}$ (Rel A) binding site in the IL-8 promoter. ${ }^{19,20)}$ Pretreatment with the antioxidant blocks $80 \%$ of NF- $\kappa \mathrm{B}$-dependent transcription and similar selective effects on NF- $\kappa \mathrm{B}$ transcription are seen with unrelated antioxidants, N-acetylcysteine (NAC) and vitamin C. ${ }^{21)}$ Matsuoka et al. reported that green tea polyphenol blocks hydrogen peroxide-induced interleukin- 8 production from human alveolar epithelial cells. ${ }^{22)}$ Our results indicate that IL- $1 \beta$ mediated IL- 8 production is ameliorated by ECG or EGCG. Thus, the antioxidative property of EGCG might be associated with the inhibition of IL-8 production through an intervening ROS pathway.

Nasal mucosal fibroblasts and bronchial epithelial cells efficiently produce IL- 8 in response to IL- $\beta$, a prototypic proinflammatory cytokine. These findings are relevant to conditions in which the resident airway cells such as fibroblasts and epithelial cells are needed to react to one of the most important early responsive cytokines, IL-1, in the host defense. After the stimulation of IL-1 stimulation, phosphorylation of $\mathrm{I} \kappa \mathrm{B}$ takes place followed by rapid degradation within the proteosome. ${ }^{23)}$

Upon pretreatment with tea polyphenols, IL-8 production is inhibited in a dose-dependent manner. Within the same phenolic group, the presence or absence of certain chemical groups and double bonds at particular locations appears crucial to the inhibitory capacity of specific molecules. Of these, the most significant are the hydroxyl groups at the A and B rings, the 2,3-double bond in the flavone skeleton, and the presence of galloyl moiety. Among the tea polyphenols tested in this study, EGCG and ECG were the most effective molecules in nasal fibroblasts at a fixed concentration of $10 \mu \mathrm{g} / \mathrm{ml}$. ECG lacks the hydroxyl group in position $3^{\prime}$ of the B ring but EGC and EC lack the hydroxyl group of the galloyl moiety. ${ }^{16)}$

In a previous report, EGCG inhibited neutrophil migration in a dose-dependent manner without the extracellular matrix barrier; EGCG seems to directly influence the neutrophils. Recently, Dona et al. reported that EGCG represses ROS and inhibits chemokine-induced neutrophil chemotaxis by acting directly on activated neutrophils. ${ }^{24)}$ Although EGCG could function on neutrophils directly, proinflammatory cytokines were good inducers of IL-8, and topical application of EGCG blocked the UVB (ultra violet B)-induced infiltration of leukocytes and subsequent generation of ROS in human skin. ${ }^{25)}$ Therefore we could assume that the major component of neutrophil-mediated inflammation is the participation of IL-8. These responses could be blocked by green tea polyphenols through the inhibition of IL-8 production in tissue resident cells such as fibroblasts and epithelial cells.

Most ingested EGCG does not enter the blood, and the absorbed EGCG is preferentially excreted through the bile to the colon. EGC and EC appear to be more bioavailable and are excreted in the urine. Therefore, the rather poor bioavailability of tea catechins should be given further consideration when extrapolating the results obtained in vitro to situations in vivo.

In conclusion, green tea may help to suppress airway inflammation by inhibiting IL-8 production in airway tissue fibroblasts and epithelial cells.

Acknowledgement This study was supported by the Kyung Hee University Research Fund in 2003 (KHU20030872).

\section{REFERENCES}

1) Luster A. D., N. Engl. J. Med., 338, 436-445 (1998).

2) Rollins B. J., Chemokines, Blood, 90, 909-928 (1997).

3) Baggiolini M., DeWald B., Moser B., Adv. Immunol., 55, 97-179 (1994).

4) Strieter R. M., Am. J. Physiol. Lung Cell Mol. Physiol., 283, 688-689 (2002).

5) Rudack C., Hermann W., Eble J., Schroeder J. M., Allergy, 57, 1159 1164 (2002).

6) Benson M., Strannegard I. L., Wennergren G., Strannegard O., Pediatr. Allergy Immunol., 10, 178-185 (1999).

7) Hill A. T., Bayley D., Stockley R. A., Am. J. Respir. Crit. Care Med., 160, 893-898 (1999).

8) Keane M. P., Arenberg D. A., Lynch J. P., III, Whyte R. I., Iannettoni M. D., Burdick M. D., Wilke C. A., Morris S. B., Glass M. C., DiGiovine B., Kunkel S. L., Strieter R. M., J. Immunol., 159, $1437-$ 1443 (1997).

9) Bruch-Gerharz D., Fehsel K., Suschek C., Michel G., Ruzicka T., Kolb-Bachofen V., J. Exp. Med.,184, 2007-2012 (1996). 
10) Nielsen O. H., Rudiger N., Gaustadnes M., Horn T., Scand. J. Gastroenterol., 32, 1028-1034 (1997).

11) Kunsch C., Rosen C. A., Mol. Cell. Biol., 13, 6137-6146 (1993).

12) Mukaida N., Okamoto S., Ishikawa Y., Matsushima K., J. Leukoc. Biol., 56, 554-558 (1994).

13) Baldwin A. S., Annu. Rev. Immunol., 14, 649-668 (1996).

14) Karin M., Ben-Neriah Y., Annu. Rev. Immunol., 18, 621-663 (2000).

15) Sartor L., Pezzato E., Dell'Aica I., Caniato R., Biggin S., Garbisa S., Biochem. Pharmacol., 64, 229-237 (2002).

16) Mathy-Hartert M., Martin G., Devel P., Deby-Dupont G., Pujol J. P., Reginster J. Y., Henrotin Y., Inflamm. Res., 52, $111-118$ (2003).

17) Sartor L., Pezzato E., Garbisa S., J. Leukoc. Biol., 71, 73-79 (2002).

18) Yang F., Oz H. S., Barve S., de Villiers W. J., McClain C. J., Varilek G. W., Mol. Pharmacol., 60, 528-533 (2001).

19) Mukaida N., Mahe Y., Matsushima K., J. Biol. Chem., 265, 21128-
21133 (1990).

20) Yasumoto K., Okamoto S., Mukaida N., Murakami S., Mai M., Matsushima K., J. Biol. Chem., 267, 22506-22511 (1992).

21) Vlahopoulos S., Boldogh I., Casola A., Brasier A. R., Blood, 94, 1878-1889 (1999).

22) Matsuoka K., Isowa N., Yoshimura T., Liu M., Wada H., Cytokine., 18, $266-273$ (2002).

23) Beg A. A., Finco T. S., Nantermet P. V., Baldwin A. S., Jr., Mol. Cell. Biol., 13, 3301-3310 (1993).

24) Dona M., Dell'Aica I., Calabrese F., Benelli R., Morini M., Albini A., Garbisa S., J. Immunol., 170, 4335- 4341 (2003).

25) Lu Y. P., Lou Y. R., Xie J. G., Peng Q. Y., Liao J., Yang C. S., Huang M. T., Conney A. H., Proc. Natl. Acad. Sci. U.S.A., 99, 12455-12460 (2002). 